\title{
Selective Abstention in Simultaneous Elections: Understanding the Turnout Gap
}

\author{
Sirus H. Dehdari* $\quad$ Jaakko Meriläinen ${ }^{\dagger} \quad$ Sven Oskarsson $^{\ddagger}$
}

December 18, 2020

\begin{abstract}
If two elections are held at the same day, why do some people choose to vote in one but to abstain in another? We argue that selective abstention is driven by the same factors that determine voter turnout. Our empirical analysis focuses on Sweden where the (aggregate) turnout gap between local and national elections has been about $2-3 \%$. Rich administrative registry data reveal that people from higher socio-economic backgrounds, immigrants, women, older individuals, and people who have been less geographically mobile are less likely to selectively abstain.
\end{abstract}

Keywords: elections, roll-off, selective abstention, voting behavior, voter turnout Word count: 4,978

*Department of Government, Uppsala University, and Swedish Institute for Social Research, Stockholm University. Email: sirus. dehdari@statsvet. uu . se.

${ }^{\dagger}$ Center for Economic Research and Department of Economics, Instituto Tecnológico Autónomo de México. Email: jaakko.merilainen@itam.mx.

$\ddagger$ Department of Government, Uppsala University. Email: sven. oskarsson@statsvet.uu . se. 


\section{Introduction}

Voter turnout varies greatly across time and space (Blais 2000). This holds true even when focusing on simultaneously held elections within countries. The notion of selective abstention is commonplace. For example, Burnham (1965) makes a remark on "[...] the tendency of the electorate to vote for 'prestige' offices but not for the lower offices on the same ballot" in the United States. This raises a puzzle. Why do some people choose to vote in one election but to abstain in another if they have already shown up at the polling station? Who are the selectively-abstaining voters?

Answering these questions is not straightforward. Voter turnout scholars have explored the connection between various individual-level characteristics and selective abstention building on both aggregate and/or survey data (Augenblick and Nicholson 2015; Bullock and Dunn 1996; McGregor 2018; Wattenberg, McAllister, and Salvanto 2000). However, inferences from aggregate data are subject to the well-understood ecological inference problem. Survey data on voter turnout, on the other hand, tend to suffer from misreporting that may be correlated with potentially unobserved voter characteristics (Holbrook and Krosnick 2009; Robinson 1950; Silver, Anderson, and Abramson 1986). Reconciling why some voters selectively abstain in elections thus requires (validated) individual-level information on voter turnout choices.

In this paper, we employ exceptional administrative registry data from Sweden where voters vote in elections at three different levels — national, regional, and municipal — at the same time. Our data combine validated voter turnout information with a plethora of individual-level characteristics. With this data set at hand, we demonstrate that individual characteristics that typically predict voter turnout (or abstention) are also associated with selective abstention. Our empirical analysis reveals that people from higher socio-economic backgrounds, immigrants, women, older individuals, and people who have been less geographically mobile are less likely to selectively abstain. Given the nature of our data, we are able to estimate these relationships while holding all institutional factors 
fixed. ${ }^{1}$ The correlations that we find are robust to a number of modeling choices, and they are in line with various arguments that link individuals' demographic and socio-economic characteristics with the costs and benefits of voting (Almond and Verba 1963; Brady, Verba, and Schlozman 1995; Verba and Nie 1972; Wolfinger and Rosenstone 1980).

In Sweden, the turnout gap between local and national elections has been about $2-3 \%$. The difference may seem small, but the aggregate number masks substantial heterogeneity. For example, in the most recent election in 2018, the turnout difference in the national and the municipal election varied between $0.7 \%$ in the municipality of Bjurholm and as much as $11.9 \%$ in the municipality of Eda (Statistics Sweden 2020). The systematic differences in the turnout base that we document may thus have meaningful consequences for public policies (Aggeborn 2016; Fowler 2013; Fujiwara 2015; Hansford and Gomez 2010). Furthermore, elections between parties and candidates are often decided by small margins. Shifts in the distribution of political power between parties and changes in the characteristics of elected officials influence policy even after close elections (Folke 2014; Hyytinen et al. 2018; Pettersson-Lidbom 2008).

The remainder of this research note is organized as follows. The following section describes our institutional context and data in detail. We discuss theoretical considerations in the third section. In the fourth section, we present our empirical analysis and findings. The fifth section concludes the study.

\footnotetext{
${ }^{1}$ Another key advantage of our data is that we are able to follow voters over time. We find that selective abstention in the past is a strong determinant of selective abstention today. This suggests that voters who cast a vote only in some of the elections do not do so by mistake.
} 


\section{Sweden as a Test Bed}

We study selective electoral participation in the context of Sweden. Elections to the Swedish Parliament, municipal councils, and county councils have been held simultaneously since $1970 .^{2}$ At present, elections are held every four years on the second Sunday of September. For the past ten years, voter turnout has exceeded $80 \%$ in all types of elections (see Figure 1), but there has been a relatively stable turnout gap between municipal and regional, and national elections. For example, in 2018 , about $87 \%$ of the voters voted in the national election but the turnout rate was roughly three percentage points lower in the local elections.

The political environment is fairly homogeneous across different types of elections. They all use the same electoral system: proportional representation with semi-open lists. Each voter may cast one vote per election that they are allowed to participate in. The candidate lists for each party are printed on separate ballot papers, and there is one party list per election. The ballots for the three elections have similar layouts but a different colors. ${ }^{3}$ A key difference between the elections at different levels are eligibility rules. To vote in a Swedish parliamentary election, one must be a Swedish citizen and at least 18 years old. Voting in elections for the county and municipal councils is less restricted. An individual is allowed to vote in these elections if he or she is at least 18 years old and a citizen in Sweden, Iceland, Norway, or any EU country. Furthermore, permanent residents who are citizens in other countries are eligible to vote if they have lived in Sweden for three consecutive years (see also Aggeborn et al. 2020).

\footnotetext{
${ }^{2}$ Municipal councils are responsible for policies such as urban planning and primary and secondary education. County councils organize health care. Therefore, both levels of government are responsible for providing important local public goods and services.

${ }^{3}$ In the United States, many elections are typically included on the same ballot. Selective voter abstention is often referred to as "roll-off", as voters are more likely to abstain in races for less salient offices that are usually listed lower on the ballot (Bowler and Donovan 2000).
} 
In our context, differential eligibility rules are one fundamental reason why inferences from aggregate data would suffer from the ecological fallacy. This calls for individual-level data if we want to understand what is behind selective abstention. Using Swedish administrative registries, we build an individual-level data set including information on voter turnout and various characteristics. Our turnout data come from the 2010 elections in which the turnout rates in the national and municipal elections were $84.6 \%$ and $81.6 \%$, respectively, and $84.4 \%$ of the voters voted in both elections (Statistics Sweden 2020). A small fraction of voters eligible to vote in both elections abstained selectively: $1.61 \%$ voted in the national but not the municipal elections, and $0.11 \%$ voted in the municipal but not the parliamentary elections. We observe the turnout outcomes and various characteristics of more than six and a half million voters in total. Appendix A provides further information on the data.

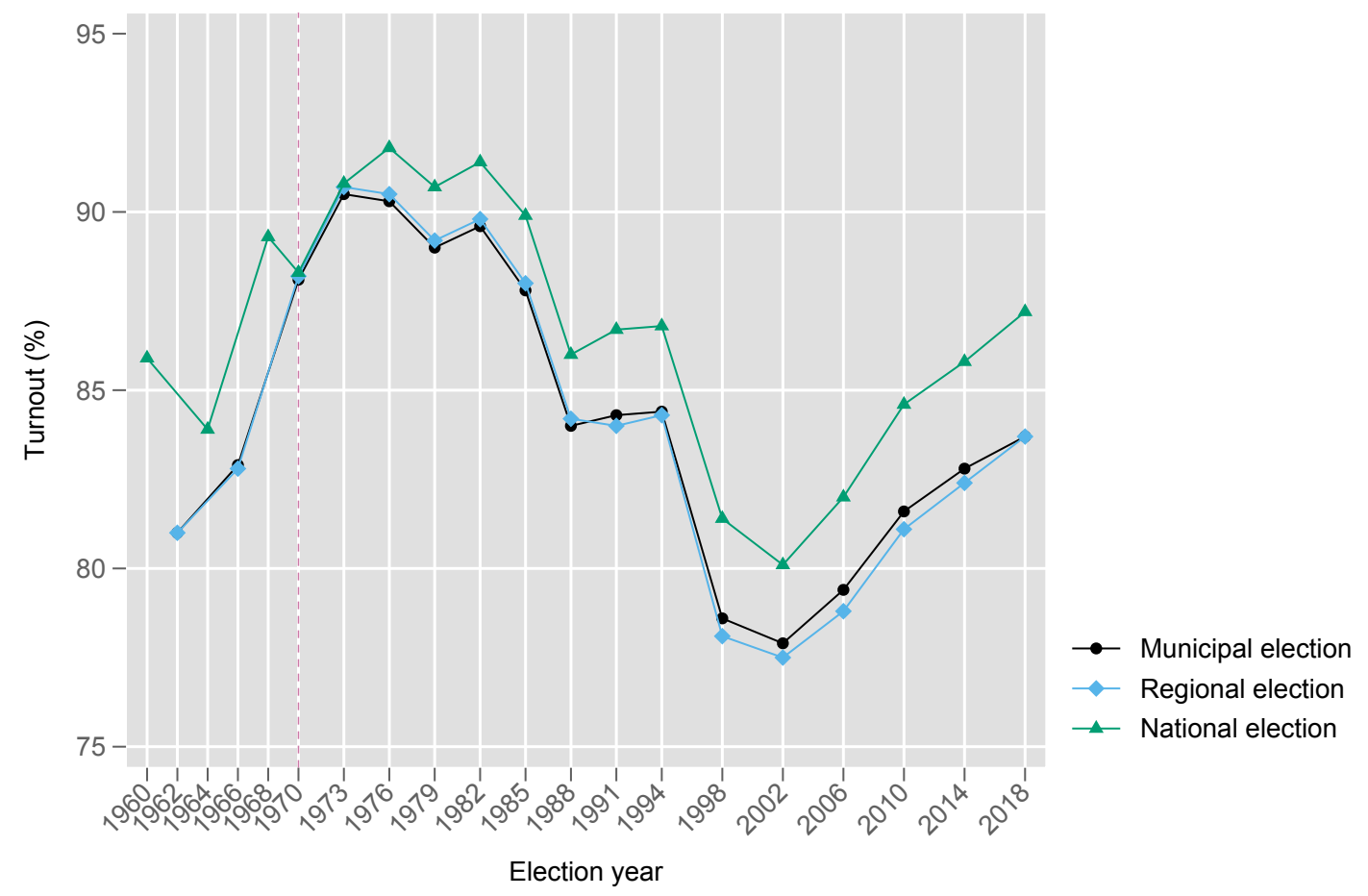

Figure 1. Turnout in Swedish elections, 1960-2018. Elections have been organized on the same day since 1970 (dashed vertical line). Source: Statistics Sweden (2020). 


\section{Theoretical Considerations}

What could explain the selective abstention that we see in our data? In this section, we provide theoretical insights on the question before proceeding to our empirical investigation. We first describe how selective abstention may be associated with the costs and benefits of voting on a more abstract level, after which we discuss how we can (indirectly) measure these factors using different socio-demographic characteristics.

Our departure point is the well-known calculus of voting framework (Downs 1957; Riker and Ordeshook 1968). ${ }^{4}$ A voter chooses to vote if the utility he or she derives from voting exceeds the cost of doing so-formally, if $p B+D>C$. Here, $p$ is the probability of an individual's vote influencing the electoral outcome, bringing the voter a benefit $B$ if realized. $D$ is an additional payoff that a voter obtains from the act of voting, such as utility from fulfilling a citizen duty, and $C$ is the cost of voting.

We argue that factors that explain voter turnout are also likely to influence selective abstention. Our focus is on $C$ and $D$ which vary across voters and which are closely connected with the socioeconomic and demographic voter characteristics that we observe. ${ }^{5}$

Theoretical work suggests that the costs explaining selective abstention are not fixed costs such as the time spent on traveling to a polling station. Instead, there are psychological informational

\footnotetext{
${ }^{4}$ See also Feddersen (2004) for a review of the rational choice theory and the paradox of not voting.

${ }^{5}$ Our empirical analyses thus abstract from the role of $p$ and $B$. Arguably, these factors could still vary across elections and shape selective abstention. For example, a single vote might be decisive in a small local government election, making $p$ greater. However, recent evidence suggests that $p$ might not have a considerable weight in voters' decisions (Enos and Fowler 2014). Andersen, Fiva, and Natvik (2014) find that voter turnout in local election increases relative to regional elections when municipalities have more financial flexibility to provide pork for voters. See also Geys (2006) for a review of aggregate-level determinants of voter turnout.
} 
costs that a voter faces if he or she has limited information on candidates and parties, and might “mistakenly" vote for the wrong candidate or party (Ghirardato and Katz 2006; Matsusaka 1995). ${ }^{6}$ These arguments are in line with Feddersen and Pesendorfer (1996) who formally show that less informed indifferent voters strictly prefer abstaining over voting, even when voting is costless.

There may also be other types of costs that matter for selective abstention. Voters who are part of a tight social network may be monitored by their peers, which could increase the cost of not voting (Feddersen 2004). Related to this argument, one might expect that voters who are more engaged with the local community may also have a greater sense of a civic duty, increasing the propensity to vote in elections at all levels of government (Leighly 1996).

Costs and benefits of voting rarely are directly observable to the researcher, and our setting is not an exception. However, research on voter turnout has pointed out that a number of socioeconomic and demographic characteristics have a strong link with such factors (Almond and Verba 1963; Brady, Verba, and Schlozman 1995; Verba and Nie 1972; Wolfinger and Rosenstone 1980). ${ }^{7}$ The emphasis of this paper is on traits that we are able to capture using the information from the Swedish administrative registries.

One of the most prominent arguments in the voter turnout literature is that citizens with a higher socio-economic status are better informed than less-educated and lower-income citizens. Therefore, they face lower (information) costs of voting which should make them less likely to selectively abstain in simultaneous elections. By the same token, many demographic

\footnotetext{
${ }^{6}$ See also Blais et al. (2019) who use data from five countries to assess the impact of voting costs on voter turnout decisions. They document that the effect of voting costs is relatively small and direct costs matters more than informational costs.

${ }^{7}$ These ideas are often referred to as the resource model of voter turnout. There are also other theories that explain turnout decisions at the individual level with mobilization, socialization, or psychological factors (see Smets and van Ham 2013 for a review and a meta-analysis of the empirical literature). We abstain from discussing these theories in detail, as we cannot test them due to data limitations.
} 
characteristics are correlated with resources of importance for the turnout decision, and also with benefits that individuals derive from the act of voting. Older people are less likely to selectively abstain, because they tend to have become more involved with public affairs and more connected with their communities. For similar reasons, geographical mobility may matter: people who have lived longer in a particular municipality are expected to be less likely to selectively abstain in local elections. Mobility could also be associated with the costs of voting. People who have recently moved to a new municipality may be less familiar with the local political environment and will therefore have to exert more effort into finding a suitable candidate or party. ${ }^{8}$ Another plausible channel through which it could matter for political behavior is home ownership (Hall and Yoder 2020): individuals who have lived a longer time in a particular location are also more likely to own property there which is also likely to boost participation in local elections. However, the data we have access to do not contain any individual-level information on home ownership and we are therefore not able to test this particular hypothesis.

In many cases, the association between individual-level traits and selective abstention is ambiguous. For instance, Kostelka, Blais, and Gidengil (2019) argue that women are less psychologically engaged in politics and thus less likely to vote in second-order elections. In contrast, authors such as Carreras (2018) have suggested that women exhibit a higher sense of civic duty than men. This should instead make them less likely to selectively abstain. Moreover, it is unclear how people with an immigrant background turn out to vote in elections at different levels. On the one hand, immigrants may come from lower socio-economic backgrounds, and they might experience language barriers to acquiring political information especially at lower-level elections. Then again, naturalization might play some role and increase voter participation, for instance, by boosting the feeling of social inclusion (Bevelander and Pendakur 2011).

\footnotetext{
${ }^{8}$ Note that, in our context, those eligible to vote are automatically registered as voters in all elections. Thus, geographical mobility cannot affect (selective) turnout through registration costs in our case (Highton 2000; Squire, Wolfinger, and Glass 1987).
} 


\section{Empirical Analysis}

We estimate a linear probability model (using OLS) to quantify the connection between voter characteristics and selective abstention in Swedish elections. We regress an indicator variable for selective abstention on a set of socio-economic and demographic covariates. Besides characteristics that influence voting behavior at the individual level, there are number of institutional and other macro-level factors that may play a role. To keep the electoral environment fixed, our specifications control for municipality fixed effects. That way, we control for all factors that are common to all voters voting in a particular municipality, such as the probability of being pivotal for the election outcome. ${ }^{9}$

We measure selective abstention using two different indicator variables: $(i)$ turning out to vote in at least one of the three elections but abstaining in at least one, or (ii) voting only in either the local or the national election which are more salient elections than the regional election. Thus, when interpreting the results it is important to bear in mind that our focus is not on turnout per se. Instead, we will estimate the effects of socio-economic and demographic factors on turnout in one but not the other election conditional on already having made it to the voting booth. ${ }^{10}$ In practice,

\footnotetext{
${ }^{9}$ We present a number of robustness checks in the Online Appendix. First, we re-estimate our models omitting municipality fixed effects. Our results remain virtually identical to those that we present here (Appendix Table B1). Second, our conclusions hold if we regress selective abstention on socio-economic and demographic characteristics separately (Appendix Tables B2 and B3). Third and last, we acquire similar results also if we use a non-linear logit specification (Appendix Table B4). Despite the dichotomous nature of the dependent variable, our main analyses are based on the OLS. The OLS specification is particularly appealing as it facilitates easier interpretation of the point estimates as well as the inclusion of the fixed effects.

${ }^{10}$ We explore alternative definitions of selective abstention in Appendix Table B5. We come to similar conclusions also if we look at selective abstention in the national or the regional election, or the regional or the local election.
} 
this means that we condition our analyses either on voting in any election, or on voting in either the local or the national election. Doing so guarantees that our findings will not be confounded by factors that matter for the initial turnout decision.

The regression results are reported in Table 1 . Note that we multiply the dependent variable by 100 so that the regression coefficients can be interpreted as percentage point changes in the probability of selective abstention. Let us start by focusing on the estimation results in columns (1) and (3). First, we see that socio-economic status matters. Earning 10,000 SEK (about 1,000 USD) more is associated with a 0.02 percentage point decrease in selective abstention, and having one more year of education is associated with a decrease of $0.22-0.29$ percentage points. These regression coefficients are statistically significant with $p<0.01$. Unemployed individuals are $0.29-0.49$ percentage points more likely to selectively abstain. Overall, these results are in line with the argument that people from higher socio-economic backgrounds have more political information which decreases the costs of voting. This further makes participation in all elections more likely.

Second, demographic characteristics are important. A one-year increase in age decreases the propensity of selective abstention by $0.06-0.08$ percentage points. Having lived one more year in a municipality prior to the election is associated with a decrease of $0.25-0.28$ percentage points in selective abstention. These results are consistent with a lower $C$ or a higher $D$ for older voters or voters who have not moved recently. Selective abstention in any election is, on average, $0.48-0.80$ percentage points lower among women than men, which is in line with the idea of female voters having a higher sense of civic duty to vote. Interestingly, a final remark is that immigrants (who are naturalized citizens) are $0.34-0.60$ percentage points more likely to vote in all elections than native Swedes. This result may seem a bit surprising given the well-known fact that immigrants in general have lower turnout rates than natives. However, once again it is important to note that the negative effect of being immigrant on selective abstention is conditional on turning up at the polls in the first place. 
To understand whether selective participation is a persistent phenomenon, or perhaps just a onetime error, we also estimate a specification in which we include the lagged dependent variable. For the purpose of this test, we use data from the 2014 elections in which we observe a random and representative sample of the voters. We link these voters to their turnout behavior in the 2010 election. If selective electoral participation is persistent, we ought to see a positive correlation between past selective abstention and selective abstention today. This is, indeed, the case (columns 2 and 4 in Table 1). In fact, past selective turnout turns out to be by far the strongest predictor of selective turnout in the current election: voters who selectively abstained in the 2010 elections are $12.6-16.46$ percentage points more likely to abstain again four years later. This stickiness in selective abstention resonates with what has been documented in the context of voter turnout decisions (Bechtel, Hangartner, and Schmid 2018; Garmann 2020).

Note also that not all of our descriptive results persist when we control for the lagged dependent variable. In particular, the regression coefficients for Years in municipality and Immigrant are no longer statistically significant. The latter even changes its sign when the additional covariate is included. The regression coefficient for Unemployed is marginally significant in column (2) but insignificant in column (4). Many of the estimates also tend towards zero when we control for lagged (selective) abstention. The discrepancies may be partially due to differences in the 2014 sample and the overall population. In Appendix Table B6, we rerun the analyses in the odd columns using the same sample of voters in 2010 . These results are very similar to the correlations that we find in the 2014 sample.

In most cases, the same characteristics that predict selective abstention also predict overall abstention. Columns (5) and (6) report the correlation between voter abstention (in all elections) and voter characteristics. There are, however, two notable exceptions. First, voters with an immigrant background are less likely to selectively abstain, conditional on having turned out to vote, but more likely to abstain overall. Second, unemployed voters are more likely to selectively abstain while they instead are less likely to abstain overall. 
We conclude our analysis by analyzing the turnout gap using data that are aggregated to the municipality level. These regression results are available in Appendix Table C1. Our exercise highlights the importance of individual-level data, if we want to properly understand what kind of factors explain selective abstention in simultaneous elections and to what extent. The patterns that we find in Table 1 do not emerge when we study the correlates of selective abstention using the aggregate-level data; some of the regression coefficients are statistically insignificant, and the magnitude of the point estimates changes considerably due to the aggregation. These remarks echo the findings of Matsusaka and Palda (1993) who compare correlates of voter turnout in Canadian survey and aggregate data, indicating that the latter specification may lead to an ecological fallacy.

\section{Closing Remarks}

We document new empirical facts on what kind of people selectively abstain in simultaneous elections. Using administrative data on voter turnout and characteristics from Swedish elections, we demonstrate that the phenomenon is associated with a set of socio-economic and demographic characteristics that are related to individuals' sense of civic duty to vote and informational costs of (not) voting. Naturally, this leaves room for further work on how other theories of voter turnout could help understanding selective abstention.

Our results have some practical implications. Voter turnout may come with wide-ranging electoral and policy consequences (Aggeborn 2016; Fowler 2013; Fujiwara 2015; Hansford and Gomez 2010). Similarly, the differences in turnout rates could be pivotal for the outcomes of local elections. In our context, close elections frequently happen within political parties (Folke, Persson, and Rickne 2016), between political parties (Folke 2014), and between party blocs (Pettersson-Lidbom 2008). Selective abstention can thus matter for representation and policy outcomes.

Moreover, knowing what type of citizens are more likely to abstain selectively can help designing policies intended to boost turnout. For example, voters who have already born the cost 
of voting might be the easiest to persuade in get-out-the-vote experiments (Green and Gerber 2015). They should also be more likely to react to information on political platforms of candidates and other important topics which should help reduce the information costs associated with voting.

Table 1. Determinants of selective and complete voter abstention.

\begin{tabular}{|c|c|c|c|c|c|c|}
\hline & \multicolumn{2}{|c|}{$\begin{array}{l}\text { Selective abstention } \\
\quad \text { (any election) }\end{array}$} & \multicolumn{2}{|c|}{$\begin{array}{l}\text { Selective abstention } \\
\text { (local or national) }\end{array}$} & \multicolumn{2}{|c|}{$\begin{array}{l}\text { Complete } \\
\text { abstention }\end{array}$} \\
\hline & (1) & (2) & (3) & (4) & (5) & (6) \\
\hline Income (10,000 SEK) & $\begin{array}{c}-0.022 * * * \\
(0.002)\end{array}$ & $\begin{array}{c}-0.011 * * * \\
(0.003)\end{array}$ & $\begin{array}{c}-0.021 * * * \\
(0.002)\end{array}$ & $\begin{array}{c}-0.009 * * * \\
(0.003)\end{array}$ & $\begin{array}{c}-0.129 * * * \\
(0.009)\end{array}$ & $\begin{array}{c}-0.076^{* * * *} \\
(0.011)\end{array}$ \\
\hline Years of education & $\begin{array}{c}-0.292 * * * \\
(0.019)\end{array}$ & $\begin{array}{c}-0.167 * * * \\
(0.031)\end{array}$ & $\begin{array}{c}-0.220 * * * \\
(0.013)\end{array}$ & $\begin{array}{c}-0.101 * * * \\
(0.024)\end{array}$ & $\begin{array}{c}-2.113 * * * \\
(0.024)\end{array}$ & $\begin{array}{c}-1.073 * * * \\
(0.055)\end{array}$ \\
\hline Unemployed & $\begin{array}{c}0.490 * * * \\
(0.056)\end{array}$ & $\begin{array}{c}0.748 \\
(0.465)\end{array}$ & $\begin{array}{l}0.285 * * * \\
(0.046)\end{array}$ & $\begin{array}{c}0.457 \\
(0.344)\end{array}$ & $\begin{array}{c}-0.653 * * * \\
(0.124)\end{array}$ & $\begin{array}{l}-1.275^{*} \\
(0.692)\end{array}$ \\
\hline Age & $\begin{array}{c}-0.083^{* * *} * \\
(0.005)\end{array}$ & $\begin{array}{c}-0.038^{* * *} \\
(0.005)\end{array}$ & $\begin{array}{c}-0.063^{* * * *} \\
(0.004)\end{array}$ & $\begin{array}{c}-0.032 * * * \\
(0.005)\end{array}$ & $\begin{array}{c}-0.088 * * * \\
(0.010)\end{array}$ & $\begin{array}{l}-0.016 \\
(0.010)\end{array}$ \\
\hline Years in municipality & $\begin{array}{c}-0.025^{* * *} \\
(0.005)\end{array}$ & $\begin{array}{l}-0.007 \\
(0.005)\end{array}$ & $\begin{array}{c}-0.028 * * * \\
(0.002)\end{array}$ & $\begin{array}{l}-0.007 * \\
(0.004)\end{array}$ & $\begin{array}{c}-0.112 * * * \\
(0.011)\end{array}$ & $\begin{array}{c}-0.032 * * * \\
(0.010)\end{array}$ \\
\hline Female & $\begin{array}{c}-0.795^{* * *} \\
(0.047)\end{array}$ & $\begin{array}{c}-0.573 * * * \\
(0.118)\end{array}$ & $\begin{array}{c}-0.483 * * * \\
(0.034)\end{array}$ & $\begin{array}{c}-0.258 * * * \\
(0.089)\end{array}$ & $\begin{array}{c}-1.672 * * * \\
(0.054)\end{array}$ & $\begin{array}{c}-1.299 * * * \\
(0.263)\end{array}$ \\
\hline Immigrant & $\begin{array}{c}-0.600 * * * \\
(0.144)\end{array}$ & $\begin{array}{c}0.272 \\
(0.269)\end{array}$ & $\begin{array}{c}-0.341 * * * \\
(0.075)\end{array}$ & $\begin{array}{l}-0.032 \\
(0.189)\end{array}$ & $\begin{array}{c}13.505^{* * *} \\
(0.418)\end{array}$ & $\begin{array}{c}7.882 * * * \\
(0.478)\end{array}$ \\
\hline Lagged dependent variable & & $\begin{array}{c}16.455 * * * \\
(1.192)\end{array}$ & & $\begin{array}{c}12.622 * * * \\
(1.236)\end{array}$ & & $\begin{array}{c}42.186 * * * * \\
(0.823)\end{array}$ \\
\hline Year & 2010 & 2014 & 2010 & 2014 & 2010 & 2014 \\
\hline Observations & 5703614 & 43197 & 5738934 & 43612 & 6643367 & 52929 \\
\hline
\end{tabular}

Notes: The dependent variable is an indicator variable (multiplied by 100) for selective abstention in any election in columns (1) and (2), selective abstention in either the local or national election in columns (3) and (4), and not voting in any election in columns (5) and (6). The estimations in columns (1) and (2) are conditional on voting in any election, and the estimations in columns (3) and (4) are conditional on voting in either the local or the national election. All specifications control for municipality fixed effects. Robust standard errors that are clustered at the municipality level are reported in parentheses. ***,** and $*$ denote statistical significance at $1 \%, 5 \%$ and $10 \%$ levels, respectively. 


\section{References}

Aggeborn, Linuz. 2016. "Voter turnout and the size of government." European Journal of Political Economy 43: 29-40.

Aggeborn, Linuz, Henrik Andersson, Sirus Håfström Dehdari, and Karl-Oskar Lindgren. 2020. “Does Election Salience Affect Immigrant Voter Turnout?” APSA Preprints.

Almond, Gabriel, and Sidney Verba. 1963. The Civic Culture: Political Attitudes and Democracy in Five Nations. New Jersey: Princeton University Press.

Andersen, Jørgen Juel, Jon H. Fiva, and Gisle James Natvik. 2014. "Voting when the stakes are high." Journal of Public Economics 110: 157-166.

Augenblick, Ned, and Scott Nicholson. 2015. "Ballot Position, Choice Fatigue, and Voter Behaviour." Review of Economic Studies 83 (12): 460-480.

Bechtel, Michael M., Dominik Hangartner, and Lukas Schmid. 2018. “Compulsory Voting, Habit Formation, and Political Participation.” Review of Economics and Statistics 100 (3): 467-476.

Bevelander, Peter, and Ravi Pendakur. 2011. "Voting and Social Inclusion in Sweden." International Migration 49 (4): 67-92.

Blais, André. 2000. To Vote or Not to Vote: The Merits and Limits of Rational Choice Theory. University of Pittsburgh Press.

Blais, André, Jean-François Daoust, Ruth Dassonneville, and Gabrielle Péloquin-Skulski. 2019. "What is the cost of voting?" Electoral Studies 59: 145-157.

Bowler, Shaun, and Todd Donovan. 2000. Demanding Choices: Opinion, Voting, and Direct Democracy. University of Michigan Press.

Brady, Henry E., Sidney Verba, and Kay Lehman Schlozman. 1995. "Beyond SES: A Resource Model of Political Participation.” American Political Science Review 89 (2): 271-294. 
Bullock, Charles S., and Richard E. Dunn. 1996. "Election Roll-Off: A Test of Three Explanations." Urban Affairs Review 32 (1): 71-86.

Burnham, Walter Dean. 1965. "The Changing Shape of the American Political Universe." American Political Science Review 59 (1): 7-28.

Carreras, Miguel. 2018. "Why no gender gap in electoral participation? A civic duty explanation." Electoral Studies 52: 36-45.

Downs, Anthony. 1957. An Economic Theory of Democracy. New York: Harper and Row.

Enos, Ryan D., and Anthony Fowler. 2014. "Pivotality and Turnout: Evidence from a Field Experiment in the Aftermath of a Tied Election." Political Science Research and Methods 2 (2): 309-319.

Feddersen, Timothy J. 2004. "Rational Choice Theory and the Paradox of Not Voting." Journal of Economic Perspectives 18 (1): 99-112.

Feddersen, Timothy J., and Wolfgang Pesendorfer. 1996. “The Swing Voter's Curse.” American Economic Review 86 (3): 408-424.

Folke, Olle. 2014. "Shades of Brown and Green: Party Effects in Proportional Election Systems." Journal of the European Economic Association 12 (5): 1361-1395.

Folke, Olle, Torsten Persson, and Johanna Rickne. 2016. “The Primary Effect: Preference Votes and Political Promotions.” American Political Science Review 110 (3): 559-578.

Fowler, Anthony. 2013. "Electoral and Policy Consequences of Voter Turnout: Evidence from Compulsory Voting in Australia." Quarterly Journal of Political Science 8 (2): 159-182.

Fujiwara, Thomas. 2015. "Voting Technology, Political Responsiveness, and Infant Health: Evidence From Brazil.” Econometrica 83 (2): 423-464. 
Garmann, Sebastian. 2020. "Political efficacy and the persistence of turnout shocks." Economics \& Politics 32 (3): 411-429.

Geys, Benny. 2006. “Explaining voter turnout: A review of aggregate-level research.” Electoral Studies 25 (4): 637-663.

Ghirardato, Paolo, and Jonathan N. Katz. 2006. "Indecision Theory: Explaining Selective Abstention in Multiple Elections.” Journal of Public Economic Theory 8: 379-400.

Green, Donald P., and Alan S. Gerber. 2015. Get Out the Vote: How to Increase Voter Turnout. Brookings Institution Press.

Hall, Andrew B., and Jesse Yoder. 2020. "Does Homeownership Influence Political Behavior? Evidence from Administrative Data.” Forthcoming in Journal of Politics.

Hansford, Thomas G., and Brad T. Gomez. 2010. "Estimating the Electoral Effects of Voter Turnout." American Political Science Review 104 (2): 268-288.

Highton, Benjamin. 2000. "Residential Mobility, Community Mobility, and Electoral Participation.” Political Behavior 2 (1): 109-120.

Holbrook, Allyson L., and Jon A. Krosnick. 2009. "Social desirability bias in voter turnout reports: Tests using the item count technique.” Public Opinion Quarterly 74 (1): 37-67.

Hyytinen, Ari, Jaakko Meriläinen, Tuukka Saarimaa, Otto Toivanen, and Janne Tukiainen. 2018. "Public Employees as Politicians: Evidence from Close Elections." American Political Science Review 112 (1): 68-81.

Kostelka, Filip, André Blais, and Elisabeth Gidengil. 2019. "Has the gender gap in voter turnout really disappeared?" West European Politics 3 (42): 437-463.

Leighly, Jan. 1996. “Group Membership and the Mobilization of Political Participation.” Journal of Politics 2 (58): 447-463. 
Matsusaka, John G. 1995. "Explaining voter turnout patterns: An information theory." Public Choice 84: 91-117.

Matsusaka, John G., and Filip Palda. 1993. "The Downsian Voter Meets the Ecological Fallacy.” Public Choice 77 (4): 855-878.

McGregor, R. Michael. 2018. "Voters Who Abstain: Explaining Abstention and Ballot Roll-Off in the 2014 Toronto Municipal Election.” Urban Affairs Review 54 (6): 1081-1106.

Pettersson-Lidbom, Per. 2008. "Do parties matter for economic outcomes? A regressiondiscontinuity approach.” Journal of the European Economic Association 6 (5): 1037-1056.

Riker, William, and Peter Ordeshook. 1968. "A Theory of the Calculus of Voting." American Political Science Review 62 (1): 25-42.

Robinson, William S. 1950. "Ecological Correlations and the Behavior of Individuals.” American Sociological Review 15 (3): 351-357.

Silver, Brian D., Barbara A. Anderson, and Paul R. Abramson. 1986. "Who Overreports Voting?" American Political Science Review 80 (2): 613-624.

Smets, Kaat, and Carolien van Ham. 2013. "The embarrassment of riches? A meta-analysis of individual-level research on voter turnout." Electoral Studies 32 (2): 344-359.

Squire, Peverill, Raymond E. Wolfinger, and David P. Glass. 1987. "Residential Mobility and Voter Turnout." American Political Science Review 81 (1): 45-65.

Statistics Sweden. 2020. "Valdeltagande i riksdags-, region- och kommunfullmäktigval efter region. Valår 1973 - 2018.” Available online at https ://www . statistikdatabasen.scb . se/pxweb/sv/ssd/START__ME__ME0104__ME0104D/ME0104T4/ (accessed December 14, 2020).

Verba, Sidney, and Norman H. Nie. 1972. Participation in America: Political Democracy and Social Equality. New York, NY: Harper \& Row. 
Wattenberg, Martin P., Ian McAllister, and Anthony Salvanto. 2000. "How Voting is Like Taking an SAT Test: An Analysis of American Voter Rolloff." American Politics Quarterly 28 (2): 234-250.

Wolfinger, Raymond, and Steven J. Rosenstone. 1980. Who Votes? New Haven, CT: Yale University Press. 


\title{
Selective Abstention in Simultaneous Elections:
}

\author{
Understanding the Turnout Gap \\ Online Appendix
}

December 18, 2020 


\section{Contents}

$\begin{array}{ll}\text { A Data } & \text { OA-3 }\end{array}$

A.1 Sample and Descriptive Statistics . . . . . . . . . . . . . . OA-3

A.2 Obtaining the Data . . . . . . . . . . . . . . . OA-4

B Robustness Checks $\quad$ OA-6

B.1 Omitting Municipality FEs $\ldots \ldots \ldots$. . . . . . . . . . . . . . . . .

B.2 Different Sets of Covariates . . . . . . . . . . . . . . . OA-6

B.3 Logit Specification . . . . . . . . . . . . . . . OA-6

B.4 Alternative Coding of the Dependent Variable . . . . . . . . . . . . . . OA-7

B.5 Estimation Results Using the 2014 Sample . . . . . . . . . . . . . . . . . OA-8

$\begin{array}{ll}\text { C Municipality-Level Results } & \text { OA-15 }\end{array}$ 


\section{A Data}

This Appendix provides further details on our data and how to acquire them for replication purposes.

\section{A.1 Sample and Descriptive Statistics}

Our data cover information on voter turnout and voter characteristics of more than six and a half million voters in total. The data were collected from Swedish municipalities that maintain voter registries and information on voter turnout. Eight out of 290 municipalities did not provide these data, and voters in these municipalities are thus excluded from our sample. Summary statistics on our data can be found in Table A1. The number of observations that we use in our analyses varies slightly depending on the specification we use. The exact numbers are reported in our regression tables. The data contain almost the whole universe of Swedish voters in the year 2010 .

The main turnout data come from the 2010 elections. In our analyses, we measure selective abstention in two ways: $(i)$ turning out to vote in at least one of the three elections but abstaining in at least one vote, or (ii) voting only in either the local or the national elections. In both cases the reference group contains individuals voting in all elections. This means that we omit individuals who reside in the region of Gotland in some of the analyses, as they do not have a regional government. According to our data, about 3\% of the voters selectively abstained in at least one election in 2010. Selective abstention in either municipal or national election was slightly lower, around $2 \%$. About $14 \%$ of the voters did not vote in any of the elections.

Besides the turnout outcomes, our data set contains information on a number of individual characteristics, in particular voters' socio-economic and demographic backgrounds. The average (monthly) income in our sample was roughly 17,500 SEK in the 2010 election. An average individual eligible to vote had completed almost 12 years of education, and $5 \%$ of the individuals in our sample were unemployed. The average age of the people included in our data set was almost 50, and they had lived roughly 22 years in the same municipality, on average. Not 
surprisingly, the data are balanced in terms of gender. As we restrict our sample to only include individuals eligible to vote in both local and national elections, the immigrants in our data are all naturalized citizens. They comprise about $9 \%$ of the observations.

In some analyses, we also use data from the 2014 election. We have information on a randomly drawn sample of individuals who were eligible to vote in the 2014 elections. When selecting this sample, higher sampling weights were placed on individuals from marginalized groups (e.g., immigrants and individuals of a lower socio-economic status). Table A1 also reports the summary statistics for the 2014 sample.

\section{A.2 Obtaining the Data}

The individual-level information that we use in this paper come from various Swedish administrative registers. The data are stored on an encrypted server at Uppsala University and all our analyses have been conducted through a remote desktop application. We are under a contractual obligation not to disseminate these data to other individuals.

However, interested readers can acquire the data directly from Statistics Sweden. Currently, Statistics Sweden requires that researchers obtain a permission from a Swedish Ethical Review Board before the data can be ordered. A description of how to order data from Statistics Sweden is available

at:

https://www.scb.se/en/services/guidance-for-researchers-and-universities/. A complete list of the variables that were used in this project is available from the authors. 
Table A1. Descriptive statistics.

\begin{tabular}{lccccc}
\hline & \multicolumn{2}{c}{2010} & & \multicolumn{2}{c}{2014} \\
\cline { 2 - 3 } \cline { 5 - 6 } & Mean & SD & & Mean & SD \\
\hline Selective abstention (any election) & 0.030 & 0.171 & & 0.033 & 0.180 \\
Selective abstention (local or national) & 0.020 & 0.140 & & 0.014 & 0.118 \\
Complete abstention & 0.138 & 0.345 & & 0.112 & 0.316 \\
Income (10,000 SEK) & 17.528 & 21.578 & & 24.132 & 24.454 \\
Years of education & 11.685 & 2.650 & & 12.216 & 2.485 \\
Unemployed & 0.048 & 0.215 & & 0.042 & 0.200 \\
Age & 49.505 & 19.085 & & 47.743 & 15.959 \\
Years in municipality & 21.886 & 15.669 & & 21.447 & 15.913 \\
Female & 0.508 & 0.500 & & 0.496 & 0.500 \\
Immigrant & 0.088 & 0.283 & & 0.091 & 0.287 \\
\hline
\end{tabular}




\section{B Robustness Checks}

In this Appendix, we show that our findings are robust to a number of alternative modeling choices.

\section{B.1 Omitting Municipality FEs}

Our main analyses control for municipality fixed effects to net out all factors that are common to all voters voting in the same election. However, our results remain unchanged if we omit the municipality fixed effects. These regression results are reported in Table B1.

\section{B.2 Different Sets of Covariates}

We start by showing that our estimation results are robust to regressing selective abstention on the socio-economic and demographic covariates separately. These regression results are reported in Tables B2 and B3, respectively. The magnitude of the point estimates is slightly affected by this modeling choice, but importantly, all qualitative conclusions remain the same as in our main analyses.

Income and years of education are negatively associated with selective and complete voter abstention, and unemployed individuals tend to be more likely to selectively abstain than employed individuals (Table B2). Age, years lived in a municipality, being a female, and being a naturalized citizen are all negatively associated with selective abstention (Table B3).

\section{B.3 Logit Specification}

In our main analysis, we estimate the relationship between different voter characteristics and selective abstention using a linear probability model (OLS). Given the dichotomous nature of our dependent variable, we have rerun our analyses using a logit specification. The logit coefficients are displayed in Table B4. The estimates obtained from this analysis are very similar to the corresponding results from the linear probability model. 
For example, focusing on the specification that do not control for the lagged dependent variable (columns 1 and 3), we can make the following observations regarding socio-economic background and voting behavior. Earning 10,000 SEK is associated with a reduction of about 0.2 percentage points in selective abstention. Similarly, individuals who have one more year of education are about $0.2-0.3$ percentage points less likely to selectively abstain. Selective abstention is about 0.4-0.5 percentage points more likely among the unemployed.

Also demographic characteristics matter in the same way as in our main analyses. A one-year increase in age and having lived in a municipality for one more year are associated with a 0.060.08 percentage point and 0.03 percentage point reduction in selective abstention, respectively. Women are 0.5-0.8 percentage points less likely to vote selectively than men and individuals with an immigrant background are 0.3-0.6 percentage points less likely to participate only in some of the elections.

When we use the 2014 sample and control for the lagged dependent variable, most of our results persist. However, as in the main analyses, the regression coefficients for unemployment and immigrant background are no longer statistically significant. While the magnitude of the coefficient for Unemployed does not change much, the coefficient for Immigrant changes sign. Having said that, it should also be noted that the standard errors are considerably larger in the specification that controls for the lagged dependent variable. In columns (2) and (4), previous selective abstention is clearly an important predictor of selective abstention today.

\section{B.4 Alternative Coding of the Dependent Variable}

In the main text, we present regression results where the dependent variable is either selective abstention in any election, or selective abstention in the national or the local election. The latter choice is due to the fact that the municipal elections are more salient than the regional elections. We present auxiliary analyses in Table B5 where we code the dependent variable in alternative ways. Columns (1) and (2) look at selective abstention in the national or the regional election, and columns (3) and (4) consider selective abstention in the regional or the local election. The signs 
of the regression coefficients align perfectly with what we present in the main text, although their magnitude is altered slightly.

\section{B.5 Estimation Results Using the 2014 Sample}

In Table B6, we assess whether the discrepancy between the results in odd and even columns in Table 1 in the main text could be driven by differences in the estimation samples that we use. The odd columns include all individuals who are eligible to vote in the elections that we focus on, whereas the even columns only include a sample of voters in the year 2014. Table B6 reports the determinants of voter turnout in this sample but using outcome data from the year 2010. The regression results using the 2010 and the 2014 data are virtually identical. This further suggests

that there may be some (potentially unobservable) differences between the populations covered by the 2014 sample and our complete data for 2010. 
Table B1. Regression results without municipality fixed effects.

\begin{tabular}{|c|c|c|c|c|c|c|}
\hline & \multicolumn{2}{|c|}{$\begin{array}{l}\text { Selective abstention } \\
\quad \text { (any election) }\end{array}$} & \multicolumn{2}{|c|}{$\begin{array}{l}\text { Selective abstention } \\
\text { (local or national) }\end{array}$} & \multicolumn{2}{|c|}{$\begin{array}{l}\text { Complete } \\
\text { abstention }\end{array}$} \\
\hline & (1) & (2) & (3) & (4) & $(5)$ & (6) \\
\hline Income (10,000 SEK) & $\begin{array}{c}-0.024 * * * \\
(0.002)\end{array}$ & $\begin{array}{c}-0.012 * * * \\
(0.003)\end{array}$ & $\begin{array}{c}-0.022 * * * \\
(0.002)\end{array}$ & $\begin{array}{c}-0.010 * * * \\
(0.003)\end{array}$ & $\begin{array}{c}-0.132 * * * \\
(0.009)\end{array}$ & $\begin{array}{c}-0.075 * * * \\
(0.011)\end{array}$ \\
\hline Years of education & $\begin{array}{c}-0.288 * * * \\
(0.013)\end{array}$ & $\begin{array}{c}-0.167 * * * \\
(0.028)\end{array}$ & $\begin{array}{c}-0.208 * * * \\
(0.011)\end{array}$ & $\begin{array}{c}-0.095 * * * \\
(0.023)\end{array}$ & $\begin{array}{c}-2.108 * * * \\
(0.023)\end{array}$ & $\begin{array}{c}-1.051 * * * \\
(0.053)\end{array}$ \\
\hline Unemployed & $\begin{array}{c}0.562 * * * \\
(0.059)\end{array}$ & $\begin{array}{l}0.823^{*} \\
(0.486)\end{array}$ & $\begin{array}{c}0.328 * * * \\
(0.050)\end{array}$ & $\begin{array}{c}0.410 \\
(0.345)\end{array}$ & $\begin{array}{c}-0.476 * * * \\
(0.145)\end{array}$ & $\begin{array}{c}-1.345^{*} \\
(0.694)\end{array}$ \\
\hline Age & $\begin{array}{c}-0.085^{* * *} * \\
(0.005)\end{array}$ & $\begin{array}{c}-0.039 * * * \\
(0.005)\end{array}$ & $\begin{array}{c}-0.066^{* * * *} \\
(0.004)\end{array}$ & $\begin{array}{c}-0.033 * * * \\
(0.004)\end{array}$ & $\begin{array}{c}-0.097 * * * \\
(0.011)\end{array}$ & $\begin{array}{c}-0.018^{*} \\
(0.010)\end{array}$ \\
\hline Years in municipality & $\begin{array}{c}-0.021 * * * \\
(0.005)\end{array}$ & $\begin{array}{l}-0.011 \\
(0.009)\end{array}$ & $\begin{array}{c}-0.021 * * * \\
(0.002)\end{array}$ & $\begin{array}{l}-0.005 \\
(0.003)\end{array}$ & $\begin{array}{c}-0.087 * * * \\
(0.008)\end{array}$ & $\begin{array}{c}-0.032 * * * \\
(0.010)\end{array}$ \\
\hline Female & $\begin{array}{c}-0.805^{* * *} * \\
(0.045)\end{array}$ & $\begin{array}{c}-0.532 * * * \\
(0.118)\end{array}$ & $\begin{array}{c}-0.487 * * * \\
(0.034)\end{array}$ & $\begin{array}{c}-0.251 * * * \\
(0.089)\end{array}$ & $\begin{array}{c}-1.688 * * * \\
(0.053)\end{array}$ & $\begin{array}{c}-1.322 * * * \\
(0.263)\end{array}$ \\
\hline Immigrant & $\begin{array}{c}-0.649 * * * \\
(0.076)\end{array}$ & $\begin{array}{c}0.129 \\
(0.291)\end{array}$ & $\begin{array}{c}-0.356 * * * \\
(0.064)\end{array}$ & $\begin{array}{l}-0.019 \\
(0.178)\end{array}$ & $\begin{array}{c}13.787 * * * \\
(0.488)\end{array}$ & $\begin{array}{c}8.365^{* * *} \\
(0.477)\end{array}$ \\
\hline Lagged dependent variable & & $\begin{array}{c}16.564 * * * \\
(1.196)\end{array}$ & & $\begin{array}{l}12.714 * * * \\
(1.241)\end{array}$ & & $\begin{array}{l}42.186 * * * \\
(0.829)\end{array}$ \\
\hline Year & 2010 & 2014 & 2010 & 2014 & 2010 & 2014 \\
\hline Observations & 5703614 & 43197 & 5738934 & 43612 & 6643367 & 52929 \\
\hline
\end{tabular}

Notes: The dependent variable is an indicator variable (multiplied by 100) for selective abstention in any election in columns (1) and (2), selective abstention in either the local or national election in columns (3) and (4), and not voting in any election in columns (5) and (6). The estimations in columns (1) and (2) are conditional on voting in any election, and the estimations in columns (3) and (4) are conditional on voting in either the local or the national election. Standard errors that are clustered at the municipality level are reported in parentheses. $* * *, * *$ and $*$ denote statistical significance at $1 \%, 5 \%$ and $10 \%$ levels, respectively. 
Table B2. Explaining voting behavior with socio-economic characteristics.

\begin{tabular}{|c|c|c|c|c|c|c|}
\hline & \multicolumn{2}{|c|}{$\begin{array}{l}\text { Selective abstention } \\
\text { (any election) }\end{array}$} & \multicolumn{2}{|c|}{$\begin{array}{c}\text { Selective abstention } \\
\text { (local or national) }\end{array}$} & \multicolumn{2}{|c|}{$\begin{array}{l}\text { Complete } \\
\text { abstention }\end{array}$} \\
\hline & (1) & (2) & (3) & (4) & (5) & (6) \\
\hline Income (10,000 SEK) & $\begin{array}{c}-0.009 * * * \\
(0.001)\end{array}$ & $\begin{array}{c}-0.006 * * \\
(0.002)\end{array}$ & $\begin{array}{c}-0.011 * * * \\
(0.001)\end{array}$ & $\begin{array}{c}-0.006 * * * \\
(0.002)\end{array}$ & $\begin{array}{c}-0.121 * * * \\
(0.007)\end{array}$ & $\begin{array}{c}-0.075 * * * \\
(0.009)\end{array}$ \\
\hline Years of education & $\begin{array}{c}-0.128 * * * \\
(0.031)\end{array}$ & $\begin{array}{c}-0.112 * * * \\
(0.033)\end{array}$ & $\begin{array}{c}-0.081 * * * \\
(0.020)\end{array}$ & $\begin{array}{c}-0.045^{* *} \\
(0.022)\end{array}$ & $\begin{array}{c}-1.831 * * * \\
(0.056)\end{array}$ & $\begin{array}{c}-1.054 * * * \\
(0.062)\end{array}$ \\
\hline Unemployed & $\begin{array}{c}1.298 * * * \\
(0.116)\end{array}$ & $\begin{array}{c}1.022 * * \\
(0.457)\end{array}$ & $\begin{array}{c}0.946 * * * \\
(0.083)\end{array}$ & $\begin{array}{c}0.681 * * \\
(0.338)\end{array}$ & $\begin{array}{c}1.686 * * * \\
(0.138)\end{array}$ & $\begin{array}{l}-0.586 \\
(0.695)\end{array}$ \\
\hline Lagged dependent variable & & $\begin{array}{c}16.861 * * * \\
(1.194)\end{array}$ & & $\begin{array}{l}13.013 * * * \\
(1.229)\end{array}$ & & $\begin{array}{c}43.361 * * * \\
(0.828)\end{array}$ \\
\hline Year & 2010 & 2014 & 2010 & 2014 & 2010 & 2014 \\
\hline Observations & 5703614 & 43197 & 5738934 & 43612 & 6643367 & 52929 \\
\hline
\end{tabular}

Notes: The dependent variable is an indicator variable (multiplied by 100) for selective abstention in any election in columns (1) and (2), selective abstention in either the local or national election in columns (3) and (4), and not voting in any election in columns (5) and (6). The estimations in columns (1) and (2) are conditional on voting in any election, and the estimations in columns (3) and (4) are conditional on voting in either the local or the national election. All specifications control for municipality fixed effects. Standard errors that are clustered at the municipality level are reported in parentheses. ***, ** and $*$ denote statistical significance at $1 \%, 5 \%$ and $10 \%$ levels, respectively. 
Table B3. Explaining voting behavior with demographic characteristics.

\begin{tabular}{|c|c|c|c|c|c|c|}
\hline & \multicolumn{2}{|c|}{$\begin{array}{l}\text { Selective abstention } \\
\text { (any election) }\end{array}$} & \multicolumn{2}{|c|}{$\begin{array}{c}\text { Selective abstention } \\
\text { (local or national) }\end{array}$} & \multicolumn{2}{|c|}{$\begin{array}{l}\text { Complete } \\
\text { abstention }\end{array}$} \\
\hline & (1) & (2) & (3) & (4) & $(5)$ & (6) \\
\hline Age & $\begin{array}{c}-0.070 * * * \\
(0.005)\end{array}$ & $\begin{array}{c}-0.031^{* * *} \\
(0.005)\end{array}$ & $\begin{array}{c}-0.052 * * * \\
(0.003)\end{array}$ & $\begin{array}{c}-0.026^{* * * *} \\
(0.004)\end{array}$ & $\begin{array}{c}0.001 \\
(0.004)\end{array}$ & $\begin{array}{c}0.037 * * * \\
(0.009)\end{array}$ \\
\hline Years in municipality & $\begin{array}{c}-0.016 * * * \\
(0.006)\end{array}$ & $\begin{array}{l}-0.002 \\
(0.005)\end{array}$ & $\begin{array}{c}-0.021 * * * \\
(0.003)\end{array}$ & $\begin{array}{l}-0.004 \\
(0.004)\end{array}$ & $\begin{array}{c}-0.048 * * * \\
(0.013)\end{array}$ & $\begin{array}{c}-0.002 \\
(0.010)\end{array}$ \\
\hline Female & $\begin{array}{c}-0.709 * * * \\
(0.043)\end{array}$ & $\begin{array}{c}-0.561 * * * \\
(0.117)\end{array}$ & $\begin{array}{c}-0.392 * * * \\
(0.029)\end{array}$ & $\begin{array}{c}-0.233^{* * *} * \\
(0.085)\end{array}$ & $\begin{array}{c}-1.304 * * * \\
(0.051)\end{array}$ & $\begin{array}{c}-1.189 * * * \\
(0.239)\end{array}$ \\
\hline Immigrant & $\begin{array}{c}-0.296 * * \\
(0.134)\end{array}$ & $\begin{array}{c}0.457^{*} \\
(0.266)\end{array}$ & $\begin{array}{l}-0.091 \\
(0.069)\end{array}$ & $\begin{array}{c}0.094 \\
(0.188)\end{array}$ & $\begin{array}{c}15.494 * * * \\
(0.567)\end{array}$ & $\begin{array}{c}8.825 * * * \\
(0.502)\end{array}$ \\
\hline Lagged dependent variable & & $\begin{array}{c}16.613 * * * \\
(1.190)\end{array}$ & & $\begin{array}{c}12.753 * * * \\
(1.233)\end{array}$ & & $\begin{array}{c}44.164 * * * \\
(0.828)\end{array}$ \\
\hline Year & 2010 & 2014 & 2010 & 2014 & 2010 & 2014 \\
\hline Observations & 5703614 & 43197 & 5738934 & 43612 & 6643367 & 52929 \\
\hline
\end{tabular}

Notes: The dependent variable is an indicator variable (multiplied by 100) for selective abstention in any election in columns (1) and (2), selective abstention in either the local or national election in columns (3) and (4), and not voting in any election in columns (5) and (6). The estimations in columns (1) and (2) are conditional on voting in any election, and the estimations in columns (3) and (4) are conditional on voting in either the local or the national election. All specifications control for municipality fixed effects. Standard errors that are clustered at the municipality level are reported in parentheses. ***, ** and $*$ denote statistical significance at $1 \%, 5 \%$ and $10 \%$ levels, respectively. 
Table B4. Results from logit estimation.

\begin{tabular}{|c|c|c|c|c|c|c|}
\hline & \multicolumn{2}{|c|}{$\begin{array}{l}\text { Selective abstention } \\
\quad \text { (any election) }\end{array}$} & \multicolumn{2}{|c|}{$\begin{array}{l}\text { Selective abstention } \\
\text { (local or national) }\end{array}$} & \multicolumn{2}{|c|}{$\begin{array}{l}\text { Complete } \\
\text { abstention }\end{array}$} \\
\hline & (1) & (2) & (3) & (4) & $(5)$ & (6) \\
\hline Income $(10,000 \mathrm{SEK})$ & $\begin{array}{c}-0.021 * * * \\
(0.001)\end{array}$ & $\begin{array}{c}-0.015^{* * *} \\
(0.004)\end{array}$ & $\begin{array}{c}-0.022 * * * \\
(0.001)\end{array}$ & $\begin{array}{c}-0.013 * * * \\
(0.004)\end{array}$ & $\begin{array}{c}-0.225^{* * *} \\
(0.003)\end{array}$ & $\begin{array}{c}-0.139 * * * \\
(0.009)\end{array}$ \\
\hline Years of education & $\begin{array}{c}-0.316^{* * *} \\
(0.014)\end{array}$ & $\begin{array}{c}-0.192 * * * \\
(0.036)\end{array}$ & $\begin{array}{c}-0.234 * * * \\
(0.008)\end{array}$ & $\begin{array}{c}-0.118 * * * \\
(0.032)\end{array}$ & $\begin{array}{c}-2.065^{* * *} \\
(0.029)\end{array}$ & $\begin{array}{c}-1.086^{* * * *} \\
(0.061)\end{array}$ \\
\hline Unemployed & $\begin{array}{c}0.535 * * * \\
(0.039)\end{array}$ & $\begin{array}{c}0.612 * * \\
(0.379)\end{array}$ & $\begin{array}{c}0.353 * * * \\
(0.028)\end{array}$ & $\begin{array}{l}0.404^{*} \\
(0.352)\end{array}$ & $\begin{array}{c}-0.402 * * * \\
(0.057)\end{array}$ & $\begin{array}{c}-1.177 * * \\
(0.548)\end{array}$ \\
\hline Age & $\begin{array}{c}-0.079 * * * \\
(0.003)\end{array}$ & $\begin{array}{c}-0.042 * * * \\
(0.006)\end{array}$ & $\begin{array}{c}-0.059 * * * \\
(0.002)\end{array}$ & $\begin{array}{c}-0.034 * * * \\
(0.006)\end{array}$ & $\begin{array}{c}-0.113 * * * \\
(0.002)\end{array}$ & $\begin{array}{c}-0.050 * * * \\
(0.009)\end{array}$ \\
\hline Years in municipality & $\begin{array}{c}-0.030 * * * \\
(0.001)\end{array}$ & $\begin{array}{l}-0.007 \\
(0.006)\end{array}$ & $\begin{array}{c}-0.032 * * * \\
(0.001)\end{array}$ & $\begin{array}{c}-0.008 * * \\
(0.005)\end{array}$ & $\begin{array}{c}-0.099 * * * \\
(0.002)\end{array}$ & $\begin{array}{c}-0.019 * * \\
(0.009)\end{array}$ \\
\hline Female & $\begin{array}{c}-0.766 * * * \\
(0.035)\end{array}$ & $\begin{array}{c}-0.586 * * * \\
(0.146)\end{array}$ & $\begin{array}{c}-0.469 * * * \\
(0.019)\end{array}$ & $\begin{array}{c}-0.265^{* *} \\
(0.129)\end{array}$ & $\begin{array}{c}-1.843 * * * \\
(0.036)\end{array}$ & $\begin{array}{c}-1.598^{* * * *} \\
(0.240)\end{array}$ \\
\hline Immigrant & $\begin{array}{c}-0.529 * * * \\
(0.033)\end{array}$ & $\begin{array}{c}0.249 \\
(0.290)\end{array}$ & $\begin{array}{c}-0.292 * * * \\
(0.022)\end{array}$ & $\begin{array}{l}-0.010 \\
(0.243)\end{array}$ & $\begin{array}{c}11.905 * * * \\
(0.176)\end{array}$ & $\begin{array}{l}5.987 * * * \\
(0.502)\end{array}$ \\
\hline Lagged dependent variable & & $\begin{array}{c}12.517 * * * \\
(1.163)\end{array}$ & & $\begin{array}{c}8.821 * * * \\
(1.232)\end{array}$ & & $\begin{array}{c}35.933 * * * \\
(0.852)\end{array}$ \\
\hline Year & 2010 & 2014 & 2010 & 2014 & 2010 & 2014 \\
\hline Observations & 5703614 & 39383 & 5738934 & 35895 & 6643367 & 52896 \\
\hline
\end{tabular}

Notes: The table shows logit coefficients. The dependent variable is an indicator variable for selective abstention in any election in columns (1) and (2), selective abstention in either the local or national election in columns (3) and (4), and not voting in any election in columns (5) and (6). The estimations in columns (1) and (2) are conditional on voting in any election, and the estimations in columns (3) and (4) are conditional on voting in either the local or the national election. ***,** and $*$ denote statistical significance at $1 \%, 5 \%$ and $10 \%$ levels, respectively. 
Table B5. Regression results for alternative dependent variables.

\begin{tabular}{|c|c|c|c|c|}
\hline & \multicolumn{2}{|c|}{$\begin{array}{l}\text { Selective abstention } \\
\text { (national or regional) }\end{array}$} & \multicolumn{2}{|c|}{$\begin{array}{l}\text { Selective abstention } \\
\text { (regional or local) }\end{array}$} \\
\hline & (1) & (2) & (3) & (4) \\
\hline Income $(10,000 \mathrm{SEK})$ & $\begin{array}{c}-0.019 * * * \\
(0.002)\end{array}$ & $\begin{array}{c}-0.009 * * * \\
(0.003)\end{array}$ & $\begin{array}{c}-0.005 * * * \\
(0.000)\end{array}$ & $\begin{array}{l}-0.003 \\
(0.002)\end{array}$ \\
\hline Years of education & $\begin{array}{c}-0.250 * * * \\
(0.018)\end{array}$ & $\begin{array}{c}-0.142 * * * \\
(0.029)\end{array}$ & $\begin{array}{c}-0.118 * * * \\
(0.013)\end{array}$ & $\begin{array}{c}-0.086 * * * \\
(0.025)\end{array}$ \\
\hline Unemployed & $\begin{array}{l}0.445^{* * * *} \\
(0.051)\end{array}$ & $\begin{array}{l}0.653 * \\
(0.395)\end{array}$ & $\begin{array}{c}0.226 * * * \\
(0.036)\end{array}$ & $\begin{array}{c}0.488 \\
(0.312)\end{array}$ \\
\hline Age & $\begin{array}{c}-0.079 * * * \\
(0.006)\end{array}$ & $\begin{array}{c}-0.035 * * * \\
(0.004)\end{array}$ & $\begin{array}{c}-0.026 * * * \\
(0.003)\end{array}$ & $\begin{array}{c}-0.015 * * * \\
(0.004)\end{array}$ \\
\hline Years in municipality & $\begin{array}{c}-0.056 * * * \\
(0.004)\end{array}$ & $\begin{array}{l}-0.012 \\
(0.009)\end{array}$ & $\begin{array}{l}-0.005 \\
(0.003)\end{array}$ & $\begin{array}{l}-0.002 \\
(0.007)\end{array}$ \\
\hline Female & $\begin{array}{c}-0.682 * * * \\
(0.041)\end{array}$ & $\begin{array}{c}-0.544 * * * \\
(0.120)\end{array}$ & $\begin{array}{c}-0.434 * * * \\
(0.022)\end{array}$ & $\begin{array}{c}-0.334 * * * \\
(0.082)\end{array}$ \\
\hline Immigrant & $\begin{array}{c}-0.652 * * * \\
(0.142)\end{array}$ & $\begin{array}{c}0.196 \\
(0.231)\end{array}$ & $\begin{array}{l}-0.161 \\
(0.102)\end{array}$ & $\begin{array}{l}0.366^{*} \\
(0.205)\end{array}$ \\
\hline Lagged dependent variable & & $\begin{array}{l}15.322 * * * \\
(1.377)\end{array}$ & & $\begin{array}{l}11.701 * * * \\
(1.452)\end{array}$ \\
\hline Year & 2010 & 2014 & 2010 & 2014 \\
\hline Observations & 5703614 & 43197 & 5738934 & 43612 \\
\hline
\end{tabular}

Notes: The dependent variable is an indicator variable (multiplied by 100) for selective abstention in either the national or the regional election in columns (1) and (2) and selective abstention in the regional or the local election in columns (3) and (4). The estimations in columns (1) and (2) are conditional on voting in either the national or the regional election, and the estimations in columns (3) and (4) are conditional on voting in either the regional or the local election. Standard errors that are clustered at the municipality level are reported in parentheses. All specifications control for municipality fixed effects. $* * * * *$ and $*$ denote statistical significance at $1 \%, 5 \%$ and $10 \%$ levels, respectively. 
Table B6. Determinants of selective and complete voter abstention (survey sample).

\begin{tabular}{|c|c|c|c|c|c|c|}
\hline & \multicolumn{2}{|c|}{$\begin{array}{l}\text { Selective abstention } \\
\quad \text { (any election) }\end{array}$} & \multicolumn{2}{|c|}{$\begin{array}{l}\text { Selective abstention } \\
\text { (local or national) }\end{array}$} & \multicolumn{2}{|c|}{$\begin{array}{l}\text { Complete } \\
\text { abstention }\end{array}$} \\
\hline & (1) & (2) & (3) & (4) & $(5)$ & (6) \\
\hline Income (10,000 SEK) & $\begin{array}{c}-0.013 * * * \\
(0.003)\end{array}$ & $\begin{array}{c}-0.011 * * * \\
(0.003)\end{array}$ & $\begin{array}{c}-0.011 * * * \\
(0.003)\end{array}$ & $\begin{array}{c}-0.009 * * * \\
(0.003)\end{array}$ & $\begin{array}{c}-0.121 * * * \\
(0.018)\end{array}$ & $\begin{array}{c}-0.076^{* * * *} \\
(0.011)\end{array}$ \\
\hline Years of education & $\begin{array}{c}-0.219 * * * \\
(0.034)\end{array}$ & $\begin{array}{c}-0.167 * * * \\
(0.031)\end{array}$ & $\begin{array}{c}-0.132 * * * \\
(0.024)\end{array}$ & $\begin{array}{c}-0.101 * * * \\
(0.024)\end{array}$ & $\begin{array}{c}-2.042 * * * \\
(0.068)\end{array}$ & $\begin{array}{c}-1.073 * * * \\
(0.055)\end{array}$ \\
\hline Unemployed & $\begin{array}{c}0.778 \\
(0.485)\end{array}$ & $\begin{array}{c}0.748 \\
(0.465)\end{array}$ & $\begin{array}{c}0.441 \\
(0.350)\end{array}$ & $\begin{array}{c}0.457 \\
(0.344)\end{array}$ & $\begin{array}{l}-0.603 \\
(0.764)\end{array}$ & $\begin{array}{c}-1.275^{*} \\
(0.692)\end{array}$ \\
\hline Age & $\begin{array}{c}-0.055^{* * *} * \\
(0.006)\end{array}$ & $\begin{array}{c}-0.038 * * * \\
(0.005)\end{array}$ & $\begin{array}{c}-0.042 * * * \\
(0.005)\end{array}$ & $\begin{array}{c}-0.032 * * * \\
(0.005)\end{array}$ & $\begin{array}{c}-0.127 * * * \\
(0.015)\end{array}$ & $\begin{array}{l}-0.016 \\
(0.010)\end{array}$ \\
\hline Years in municipality & $\begin{array}{c}-0.011 * * \\
(0.005)\end{array}$ & $\begin{array}{l}-0.007 \\
(0.005)\end{array}$ & $\begin{array}{c}-0.011 * * * \\
(0.004)\end{array}$ & $\begin{array}{c}-0.007^{*} \\
(0.004)\end{array}$ & $\begin{array}{c}-0.074 * * * \\
(0.014)\end{array}$ & $\begin{array}{c}-0.032 * * * \\
(0.010)\end{array}$ \\
\hline Female & $\begin{array}{c}-0.716^{* * * *} \\
(0.125)\end{array}$ & $\begin{array}{c}-0.573 * * * \\
(0.118)\end{array}$ & $\begin{array}{c}-0.311 * * * \\
(0.094)\end{array}$ & $\begin{array}{c}-0.258 * * * \\
(0.089)\end{array}$ & $\begin{array}{c}-2.447 * * * \\
(0.336)\end{array}$ & $\begin{array}{c}-1.299 * * * \\
(0.263)\end{array}$ \\
\hline Immigrant & $\begin{array}{c}0.239 \\
(0.273)\end{array}$ & $\begin{array}{c}0.272 \\
(0.269)\end{array}$ & $\begin{array}{l}-0.042 \\
(0.186)\end{array}$ & $\begin{array}{l}-0.032 \\
(0.189)\end{array}$ & $\begin{array}{c}13.552 * * * \\
(0.529)\end{array}$ & $\begin{array}{c}7.882 * * * \\
(0.478)\end{array}$ \\
\hline Lagged dependent variable & & $\begin{array}{c}16.455 * * * \\
(1.192)\end{array}$ & & $\begin{array}{c}12.622 * * * \\
(1.236)\end{array}$ & & $\begin{array}{l}42.186 * * * \\
(0.823)\end{array}$ \\
\hline Year & 2014 & 2014 & 2014 & 2014 & 2014 & 2014 \\
\hline Observations & 43197 & 43197 & 43612 & 43612 & 52929 & 52929 \\
\hline
\end{tabular}

Notes: The dependent variable is an indicator variable (multiplied by 100) for selective abstention in any election in columns (1) and (2), selective abstention in either the local or national election in columns (3) and (4), and not voting in any election in columns (5) and (6). The estimations in columns (1) and (2) are conditional on voting in any election, and the estimations in columns (3) and (4) are conditional on voting in either the local or the national election. All regressions control for municipality fixed effects. Standard errors that are clustered at the municipality level are reported in parentheses. $* * *, * *$ and $*$ denote statistical significance at $1 \%, 5 \%$ and $10 \%$ levels, respectively. 


\section{Municipality-Level Results}

An important remark is that the correlations that we find when using the individual-level do not show up when we aggregate the data to the municipality level by taking averages. We illustrate this point in Table $\mathrm{C} 1$.

Income, age, and immigration status are still correlated with selective (columns 1 and 2) and complete (column 3) abstention similarly to what our individual-level analysis suggests. However, we no longer see that average duration of education, unemployment status, years lived in the municipality, or gender composition would matter for selective abstention. Also the magnitude of the point estimates is affected by the aggregation. This makes it more difficult to make any inferences regarding the association between selective abstention and individual voter characteristics. These remarks further highlight the importance of individual-level data if we want to study the determinants of (selective) abstention.

Note that there is one observation missing in column (1). This is due to the fact that the region of Gotland only has one municipality and it does not have a regional government. Thus, we omit this municipality from the analysis. 
Table C1. Regression results obtained with aggregate data.

\begin{tabular}{|c|c|c|c|}
\hline & $\begin{array}{l}\text { Selective abstention } \\
\text { (any election) }\end{array}$ & $\begin{array}{c}\text { Selective abstention } \\
\text { (local or national) }\end{array}$ & $\begin{array}{l}\text { Complete } \\
\text { abstention }\end{array}$ \\
\hline & (1) & (2) & (3) \\
\hline \multirow[t]{2}{*}{ Income $(10,000 \mathrm{SEK})$} & $-0.111 * * *$ & $-0.099 * * *$ & $-0.480 * * *$ \\
\hline & $(0.032)$ & $(0.022)$ & $(0.086)$ \\
\hline \multirow[t]{2}{*}{ Years of education } & 0.036 & 0.097 & $-0.797 * *$ \\
\hline & $(0.182)$ & $(0.114)$ & $(0.390)$ \\
\hline \multirow[t]{2}{*}{ Unemployed } & 3.511 & 2.567 & 19.929 \\
\hline & $(4.802)$ & $(2.731)$ & $(13.303)$ \\
\hline \multirow[t]{2}{*}{ Age } & $-0.099 * *$ & $-0.145 * * *$ & -0.014 \\
\hline & $(0.040)$ & $(0.026)$ & $(0.085)$ \\
\hline \multirow[t]{2}{*}{ Years in municipality } & -0.009 & 0.002 & 0.027 \\
\hline & $(0.007)$ & $(0.004)$ & $(0.018)$ \\
\hline \multirow[t]{2}{*}{ Female } & 4.736 & 6.024 & $-43.880 * * *$ \\
\hline & $(6.725)$ & $(4.063)$ & $(16.636)$ \\
\hline \multirow[t]{2}{*}{ Immigrant } & $-5.829 * * *$ & $-4.554 * * *$ & $21.728 * * *$ \\
\hline & $(1.328)$ & $(0.838)$ & $(2.548)$ \\
\hline Year & 2010 & 2010 & 2010 \\
\hline Observations & 281 & 282 & 282 \\
\hline
\end{tabular}

Notes: The dependent variable is the share of voters who selectively abstain in any election in column (1), who abstain in either the local or national election in column (2), and who do not vote in any election in column (3) Standard errors that are clustered at the municipality level are reported in parentheses. $* * *, * *$ and $*$ denote statistical significance at $1 \%, 5 \%$ and $10 \%$ levels, respectively. 